\title{
Vectors of Innovation Definition for Application During Conceptual Design Stage of Product Development Process
}

\author{
Juliane de Bassi Padilha ${ }^{1 *}$, Carlos Cziulik ${ }^{1}$, Paulo André de Camargo Beltrão ${ }^{1}$
}

\begin{abstract}
The quest for product with unique attributes and added value, along with the shortening of product life cycle are directly related to the degree of competitiveness of organizations. The identification of innovation opportunities in the early stages of the product development process is seen as a means for increasing competitiveness. Among those stages that have relevant impacts during the design process, is conceptual design, when many important decisions related to the degree of novelty of a design solution are taken. This study aims at identifying elements connected to innovation issues that can contribute to the selection of conceptual proposals that have potential to be transformed into novel and successful products. To map these elements, a literature review was conducted in parallel with a reverse analysis of a set of so called innovative products. From the recognition and grouping of these elements that can induce innovation, a field research was conducted with professional designers in order to identify if they recognized the set of elements as representing vectors of innovation, as well as, their relative importance. Next, a descriptive application was run, considering a real design situation extracted from literature, illustrating how to select a conceptual design solution that presents the greater potential for innovation, from the set of elements identified. Thus, this study provides the identification and determination of degrees of importance for inducing elements innovation in order to demonstrate the possibility of assessing potential for innovation in the early stages of the product development process.
\end{abstract}

Keywords: innovation; conceptual design; selection of alternatives; early stages of product development process.

Submitted: Jun $30^{\text {th }} 2016 /$ Approved: November $16^{\text {th }} 2016$

\section{Introduction}

Considering the current scenario of economic contention companies are required, at least, to maintain their level of competitiveness, so they can keep the business going. Also since the customers are better informed, they look for products that exceed their expectations, usually presenting attributes that differentiate them in the market. It is also being observed the need to launch new products at shorter intervals, mainly due to the reduction of the product life cycle (Coral; Ogliari; Abreu, 2008).

Xie et al. (2016) argue that knowledge, as both a source of power and a resource, is strategically important for innovation activity. Companies should look for ways to enhance the development of knowledge and use it effectively. Organizations that always follow the same pattern, working with products and saturated technologies, tend to lose its share in the market. From these observations, it is possible to understand that innovation becomes an essential requirement during the PDP (Product Development Process). The definitions reflect a common idea in which innovation is a process conducted since the invention (the basic idea, sketch or model for a project, product, process or new (or enhanced) system) to the results dissemination for a group of potential customers (Padilha, 2008). The conversion of this new idea into a product involves various activities such as research, design, development, embodiment engineering and manufacturing, among others. Therefore, innovation should be inserted into a systematic process, so it will not occur randomly (Pahl et al., 2005; Rozenfeld et al., 2006; Coral; Ogliari; Abreu, 2008; Back et al., 2008).
The innovation comprises a complex and multidisciplinary arena in which the new products development process should be considered as a core component. Decisions taken during the PDP can directly influence the outcome expected to be achieved (i.e. innovation), in addition to the regular and planned activities that constitute the PDP (Zabala- Iturriagagoitia, 2012).

The PDP models found in several references are composed of several stages. It is during the conceptual design stage that principles of solution that define the final product are identified (Back et al., 2008). The selection process defines which concepts should be developed and those that must be abandoned. Thus, this stage can be seen as a gatekeeper of creative ideas that can lead to innovative products (Toh; Miller, 2015). Therefore, identifying elements that are innovation inducers, at early stages of the PDP, enables creative ideas to be promptly identified and matured so that they can result in a product with a potential of innovation.

From this context, this paper aims at identifying elements/criteria that can be used by the design team as vectors of innovation, during the early stages of the PDP. The research approach is based on an extensive literature review, coupled with a reverse analysis of five products considered innovative. The matches identified are described as innovations inducers and will be called elements that can integrate the framework for the decision-making process when the focus is centered on innovation. They were validated by a field survey with design professionals, who also defined their relative importance. An exemplifying application, structured from a real design case illustrates the approach developed.

(1) PPGEM - Post-graduate Programme in Mechanical and Materials Engineering Federal University of Technology - Parana, Brazil *Corresponding author: julianepadilha@utfpr.edu.br 


\section{Theoretical Background}

The literature highlights the importance of innovation capability as a critical success factor for the growth of organizations and the only means by which companies can obtain competitive advantage (Ukko, Saunila, 2013). There are various definitions and concepts related to the innovation term. The Oslo Manual (OECD, 2005) contains a general definition in which an innovation is the implementation of a product (good or service), new or improved, a process, a marketing method, or organizational method in the business practices, in the working arrangement or external relations. ).

Zawislak et al. (2008) define innovation as the application of knowledge to generate technical or organizational changes capable of offering benefits to the company that produces it. This knowledge is new to the business, but not necessarily new to its competitors, to the market or the world. Thus, incremental changes would be in the center of the innovation process in developing countries.

The systematization of the new products development allows the company to identify opportunities, set priorities of their projects and optimize time and costs. "For organizations to ensure sustainability and launch new products/services systematically and continuously, they need to manage with caution the innovation issues" (Carvalho; Reis; Cavalcante, 2011, p. 55).

Product development is an activity that encompasses aspects of planning and design, from market research, through product design, manufacturing process design, distribution and maintenance plan, product use and its disposal. Thus, the product development should be seen as a holistic process "...transformation process of information needed for identifying the application, production and use of the product" (Back et al., 2008, p. 04).

Tondolo et al. (2012) consider two main streams for product development: i) the NPDP (new product development process) in a very close connection to radical innovations. In this case, the company must develop new management processes, new technologies, new materials or tools; and ii) PDP (product development process) in a context that includes any change in the product, including minor modifications or improvements implemented into existing products.

Among the stages that integrate the PDP it is during the conceptual design phase that, from the design specifications, concepts for a product are developed (Coral; Ogliari; Abreu, 2008). Li et al. (2009) emphasize the importance of design stage, in which it is possible to determine the level of innovation of the final product. Errors at this moment can compromise 70 to $80 \%$ of the investment allocated to the project. It is important to highlight that the term "product" refers to an idealized object, produced on an industrial scale, that has features and functions, which aim to meet desires or needs from customers or organizations, to whom it will be marketed. Usually, the attributes that are relevant for products are: appearance, shape,color function, image, material, packaging, brand, after-sales service and warranty (Back et al., 2008).
The Conceptual Design phase is characterized by the search, creation, representation and selection of solutions (Back et al., 2008). The central difficulty for the concept selection process is the main feature of the conceptual design phase: technical information is still limited and abstract (Rozenfeld et al., 2006). Pahl et al. (2005) state that there is no absolutely safe method that prevents there is no completely safe method that avoids wrong decisions to be taken. However, they reinforce that the use of systematic and verifiable selection methods enable a better management of this activity.

About the process of selection of alternatives, the literature points to the existence of models and tools that are intended to assist the design team, identifying desirable parameters or attributes into the product concept to be developed. These parameters enable a qualitative and quantitative evaluation of the solutions proposed using of weights and valuation of their attributes (Back et al., 2008). However, there is a lack of specific criteria with the focus on innovation aspects. Very often, innovation is one of the criteria to be evaluated and not the central point of the evaluation process.

Yilmaz and Seifert (2011) highlight the use of heuristics in the process of product ideation as a way to drive new possible solutions for the design problem. These heuristics may also serve as a starting point for the transformation of an existing concept into a set of new ideas. The authors gathered 21 heuristics observed during the evaluation of 50 sketches. The study by Yilmaz and Seifert (2011) aimed to describe the design heuristics, considering form and function issues, to identify transformational steps that can assist the design team in presenting a systematic variation in their current concepts, leading to a diversity of products in the company's portfolio.

To evaluate and select an alternative solution for a design problem, criteria related to the use, appearance, ergonomics, production, costs, among others, can be employed. Therefore, "a complete set of principle solution models should be developed to reach the so-called product concept models" (Rozenfeld et al., 2006, p. 265).

Rozenfeld et al. (2006) point to the importance of material definition during the development and selection of conceptual alternatives. Often, this selection is based on previous design decisions, limiting the possibility of adopting new materials, thus restricting the opportunity to innovate, by the usage of a new material or a new application for an already known material. A full understanding of functions implemented by industrial products can be valuable during the concept generation stage. Since certain products may be more related to a particular type of use than others, this factor can represent a differential attribute when designing a product.

Lobach (2001) states that the relations between customers and industrial products are those functions that the product implements. The functions are related to the consumer requirements satisfaction. The author highlights three types of functions: i) practical (related to the physiological aspects of the product usage), ii) Aesthetic (concerns the psychological aspect of sensory perception when using a product); and iii) symbolic (refers the psychological and social issues of a product handling). 
During the process of developing suitable principle solutions (and, therefore, concepts), several factors should be considered: i) methods that help the searching for creative solutions, whether intuitive or systematic; ii) definition of the product architecture; iii) analysis of systems/subsystems/components; iv) identification of possible materials and production processes; v) forecast of aspects about life cycle of the product and vi) ergonomic issues and inter-relationship with the end-user (Rozenfeld et al., 2006).

Back et al. (2008) established a set of criteria that represent typical product attributes and can provide support in the process of selecting conceptual design alternatives. They are classified as i) elementary basic attributes (functionality, ergonomics, aesthetics, security, reliability, liability, patenting, standardization, robustness, environmental impact); ii) attributes of the life cycle (manufacturability, assembly ability packaging, transportability, storability, marketability, usability, maintainability, recyclability, disability; and iii) specific attributes (geometry, kinematics, forces, energy, materials, signs, automation). Several authors emphasize that the criteria should be clear, independent, unambiguous and equally applicable to all conceptions (Pahl et al., 2005; Back et al., 2008).

Sarkar and Chakrabarti (2011) state that an approach to assess the novelty of a product is through of products comparison with the same function. If no other product fulfils the same set of requirements, the proposed product design can be regarded with some degree of novelty. In the SAPPHIRE model proposed by Sarkar and Chakrabarti (2011), the level of novelty of a product can be framed as high, medium or low. Usually, when designing a new product, the information available at early stages of the design process is still abstract. Thus, it is necessary to identify which elements can convey the innovation to the customer, so these parameters can be used to assess in defining how potentially innovative is a design about others.

\section{Research method}

In this section, a planning and deployment of a reverse analysis is described. It involved the selection and in-depth examination of five Brazilian products, recognized as innovative (either by the awards received or by the positive customer response). From the literature review, innovation vectors were compiled. Next, this set was crossreferenced with the products selected, to confirm (or reject) their occurrence in practice. From that, a particular set of elements (innovation inducers) was identified, which can be applied in several activities at the early stages of the PDP, especially, during the conceptual design stage.

\section{Assumptions}

During the literature review, elements that can induce innovation were identified, which can assist in mapping innovative features on the product being developed. However, they these elements are not correctly grouped and classified to permit an evaluation focused on assessing the innovation potential of a conceptual design alternative. The evaluation criteria that support the assessment process is usually derived from items that integrate the product design specification (Pahl et al., 2005), which are of qualitative nature and are not directly addressed to innovation. Therefore, this study aimed at complementing and validating the identification of these elements by a reverse analysis conducted with five household products.

It has been assumed that if it is possible to recognize, in current products on the market, elements that characterize innovation, they can be used as vectors to, either develop conceptual design alternatives or identify the solution with the strongest innovation potential.

\section{Procedures}

The selection of the existing products, objects of this study, was based on awards won and customer response about their degree of novelty. The reference products from the household appliances sector (e.g. cleaning devices, furniture). Information regarding the products was obtained through reports, magazines, specialized literature and, in some cases, companies' websites. Thus, the procedure adopted to implement the reverse analysis involved the following steps:

1. Identification and selection of products considered to be innovative in the Brazilian market;

2. Organization that indicates that the product selected is innovative;

3. Mapping the elements that characterize the product as being innovative.

\section{Reverse analysis: implementation}

Tables 1 to 5 show each product selected, its description, the awards received and the identification of the elements that characterize these products as being innovative. 
Table 1. SUPERPOP Washing Machine. Source: Museu da Casa Brasileira (2006).

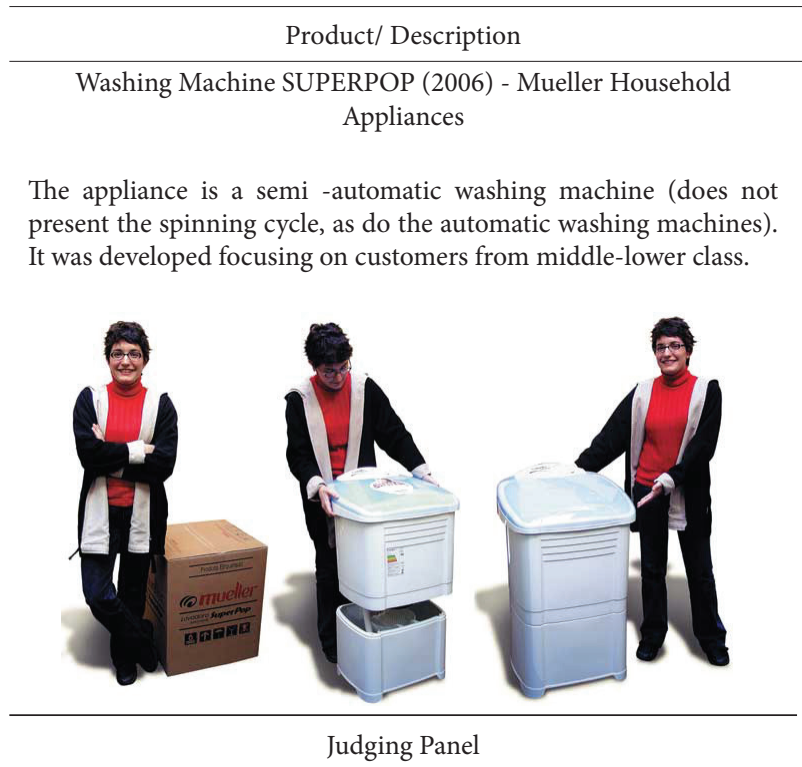

- Award Mercado Design - Top XXI, sponsored by the magazine ARC Design; 20th Brazilian House Museum Award (2006); 37th Edition of National Top of the Marketing ADVB (Sales and Marketing Directors Association of Brazil).
Innovative Characteristics

- The machine is sold disassembled. This results in a package $40 \%$ smaller than the traditional ones. This reduced the cost of shipping the product and the need for space for storage in warehouses; (Transport)

- There are specific side spaces so the final user can easily carry the product; (Ergonomics)

- The customers can take the washing machine home at the moment of purchasing This avoids delivering taxes and waiting time; (Transport)

- The design team chose to divide into two parts the traditional washing machine cabinet. Thus, the bottom part (which is smaller), can fit into the upper part (which is larger). This generates a compact packing, ideal for transporting; (Manufacturing and Transport)

- The design adds value to the product, with focus on cost reduction without compromising the aesthetic, which influences the self-esteem of the low-income targeted customer (statues issues); (Form)

* Research and development in the manufacturing process has enabled the production of a transparent version of the product called "Superpop Glass", launched in March 2007. This is the first transparent washing machine in the Brazilian market.

Table 2. TRILOBITE Vacuum Cleaner. Source: Electrolux (2016).

Product/ Description Innovative Characteristics

TRILOBITE Vaccum Cleaner (2001) - Electrolux

Vacuum cleaner that has capabilities to self-guide, inside the room boundaries. It performs the task of removing particles without human assistance. It is powered by rechargeable nickel batteries.
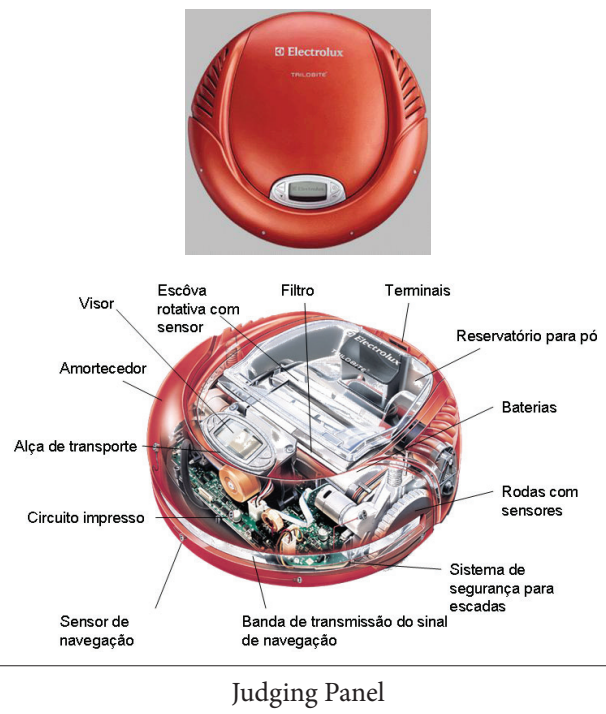

- Survey with Trilobite owners indicated a high degree of satisfaction. The main reasons that led people to buy the product were: i) high technology - 67\%; ii ) convenient - $46 \%$; iii ) "fun " $56 \%$; iv ) practical - $53 \%$; v) new design - $50 \%$; vi) saves time - $39 \%$; and vii ) "personal” - $17 \%$.
- Display that provides product information for the user; (Ergonomics)

- Use of ultrasound (analogy with the bat) to avoid obstacles such as table legs and pets. The system determine the dimensions of a room and the best route that can be followed during the cleaning process; (Technology)

- Use of magnetic tapes to establish the boundaries of the area to be cleaned; (Technology)

- The aesthetic design of the product (analogy with trilobites - extinct marine arthropod), harmonious and organic lines, differentiate Trilobite from other existing vacuum cleaners; (Form)

- Ability to set different levels of aspiration (normal, fast, specific), according to the user's needs; (Function)

* Other companies have already developed prototype of robots that work as vacuum cleaners. However, Trilobite was the first to be traded. 
Table 3. JANGADA Furniture Collection. Source: Museu da Casa Brasileira (2001a); Grilli, Silvia (2015).

Product/ Description Innovative Characteristics

JANGADA Furniture Line (2001)

Kakakis Industry and Commerce of Furniture Limited

- "Jangada" Furniture Line consists of a series of chairs, tables, bookcases and armchairs inspired by the same name ship. The concept of this type of ship generated several alternatives in the development of the collection.

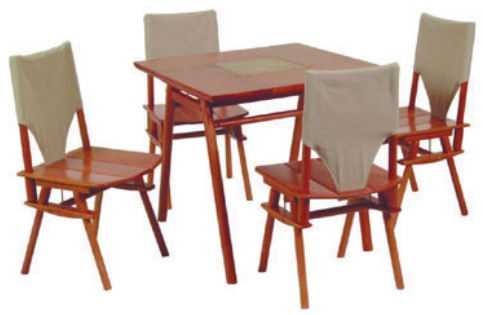

- Simplification of the production process through tapered fittings, merging pressure and friction, therefore without the use of nails; (Manufacturing)

- Constructive details originated a collection of products with its own aesthetic characteristics. It emphasizes and enhances elements from the local culture, which creates its own unique identity; (Form)

- The rational and differentiated use of the raw material - reforested wood (Lyptus, an hybrid from Eucalyptus urophilla and Eucalyptus grandis), which certifies and customizes the product; (Manufacturing)

Judging Panel

The chairs from Jangada collection are collapsible. The furniture in the collection can be easily assembled by the user. (Transport)

- Honorable Mention at the 15 th Brazilian House Museum Award (2001), by Enora chair design; Honorable Mention in Movelsul Design Competition 2002, by the Minburá chair. The complete furniture collection was a finalist in the same competition. Honorable Mention in Expodema Design Regional Competition, in Argentina, by the Tauaçu chair design; The Jangada collection was exhibited at the Salon Satellite 2003, in Milan, Italy.

Table 4. SPIRIT Ceiling Fan. Source: Museu da Casa Brasileira (2001b).

\begin{tabular}{cc}
\hline Product/ Description & Innovative Characteristics \\
\hline SPIRIT Ceiling Fan (2001) - Plajet
\end{tabular}

Ceiling Fan, manufactured in polycarbonate, which adopts minimalist style. It consists of three pieces in different colors

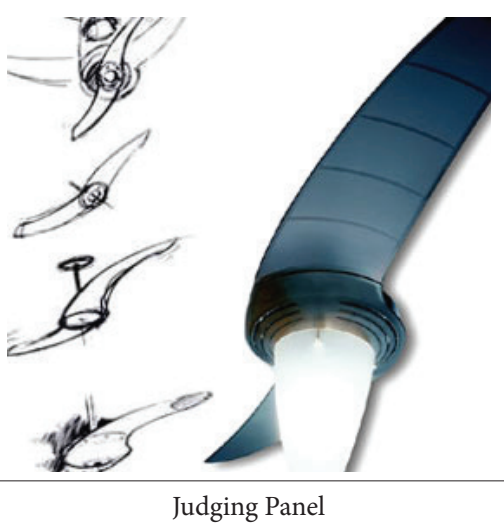

- Second Place at the 15th Brazilian House Museum Award, 2001. IF Design Award 2002 - Category: Building. Ecodesign Award 2003 - Fiesp. Moinho Santista Award 2003; IF Design Award 2004 - Category: Lighting. Top of Marketing ADVB Rio 2003 and 2004. Rio Faz Design Award 2004 and 2006; POPAI (Point of Purchase Advertise International) 2004. The Bizz Awards 2005. Marketing and International Business Award 2004. Quality Award Brazil 2005. IF Design Hannover Award, in 2005 ..
- Minimization of parts and simplification of the product. Most ceiling fans in the market have at least seven pieces. The Spirit fan has its core composed of three parts; (Manufacturing)

- Integration of form and function: its design, inspired by the propellers of the aircraft, is intended to optimize its aerodynamics, generating a performance $30 \%$ superior than average fans in the market; (Form and Function)

- Differential in the material. Existing fans in the market are assembled with three or more blades in wood and steel casing, which generates low ventilation and does not provide a good integration with the chandelier; (Function and Manufacturing)

- Raw material. It uses, basically, polycarbonate, which is a recyclable material, light, with great strength (including the marine air); (Manufacturing)

- Due to the variety of colors available, it allows several combinations with the chandelier (better integration). Most fans have more than 20 years of existence, with few variations in designs, colours and chandeliers; (Form)

* With the awards received, the Spirit enabled the company to develop a strong marketing strategy, further strengthening the product brand in the market. The percentage of revenues spent on design (around $2 \%$ ), incremented the revenues by, approximately, $50 \%$. 
Table 5. DUO FLUX Flushing Valve. Source: Museu da Casa Brasileira (2005).

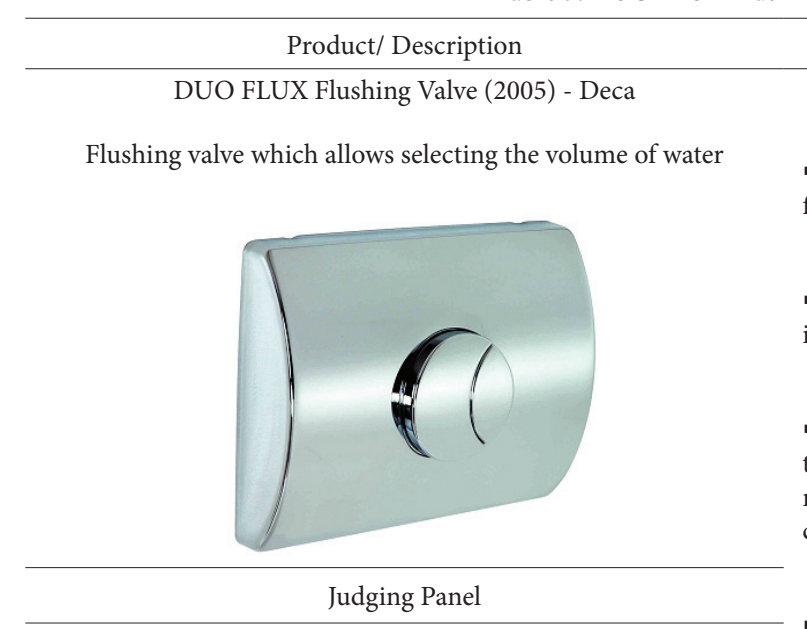

First Prize at the 19th Brazilian House Museum Award (2005), Category: Construction equipment; Market Design Award - Top 21 (2007 ) Category: Bathroom equipment.
- The innovative design of its finishing allows the identification of the type of intended flushing, with more water (big button) or less water (small button); (Function)

- The product can be installed either horizontally or vertically, replacing existing valves, increasing water savings and avoiding waste; (Form)

- Pressing the small, an inner restrictor is activated, releasing a flow of approximately three liters of water per flush, allowing water savings. The larger button does not trigger flow restrictor, permitting a complete flushing, ideal for the removal of solid wastes. The product can be installed in single or double-story houses, or multi-story apartments; (Function)

Its working principle, with two flushing options, is suitable for any type of sanitary bowl and can be adapted to existing facilities. (Transport)
After finishing the analysis of the products in the set, it was possible to identify and group elements (highlighted in italics), in the column "Innovative Characteristics" that confirm the innovation occurrence for the examined context. The next step was to seek the theoretical definitions that confirm (or reject) these elements as being central to the customer's perception of product innovation.

Thus, six elements were identified and are presented next:

a. Ergonomics: the heuristics demonstrated by Yilmaz and Seifert (2011), "Adjust according to the different needs of users" and "Change the way you physically interact with the system" are references that support to enlist this element as a possible criterion to assess a potentially innovative design. Rozenfeld et al. (2006) also indicate "ergonomics" as a requirement to be evaluated in the selection of alternatives. In the reverse analysis procedure, ergonomics is highlighted in two products: Trilobite vacuum cleaner and Superpop washing machine;

b. Form: Lobach (2001) and Rozenfeld et al. (2006) reinforce the importance of aesthetic and formal issues when differentiation is a major requirement in the product development. Lobach (2001) also emphasizes the psychological and social aspects of a product as a means for promoting the distinction between products. In the reverse analysis procedure, form was addressed on all situations in the set;

c. Function: the heuristics presented by Yilmaz and Seifert (2011), "Applying an existing mechanism in a new way" and "Using a common element for multiple functions" supports that function can be used to assess the innovation potential of a design solution. Similarly, Rozenfeld et al. (2006) emphasize that the product architecture is how the functional elements can be arranged, as well as, defines the ways of their interaction. Knowing these arrangements can contribute to the ideation of differentiated solutions. During the reverse analysis activity, function was strongly perceived in three products: i) Trilobite vacuum cleaner; ii) Spirit ceiling fan; and iii) Duo Flux flushing valve;

d. Manufacturing: among the heuristics cited by Yilmaz and Seifert (2011), there is: "Merge a variety of parts ; "Add, remove or bend components that are not in use"; "Replace an element for another one"; and "Divide a component into several smaller pieces as principles that allow variation of manufacturing solutions. Furthermore, Rozenfeld et al. (2006) affirm that the decisions related to materials selection (whether a new material or a new way of using an already known material) can be an opportunity to leverage innovation in the set of design alternatives. Manufacturing was detected as a major issue during the reverse analysis in three products: Jangada furniture line, Spirit ceiling fan and Superpop washing machine;

e. Technology: Back et al. (2008) indicate that products specific attributes, such as: "force", "energy", "signal", "automation" and "time" can serve as a basis for identifying differentiated design solutions. Similarly, Tondolo et al. (2012) highlight the importance of developing new technologies as an element of implement differentiation into a product. During reverse analysis, technology as innovation vector was observed in the Trilobite vacuum cleaner;

f. Transport: Back et al. (2008) have listed a set of attributes related to the life cycle, such as: "assembly ability," "packaging," "transportability" and "storability." These attributes can orient the selection process when seeking for differents design solutions. Transport was identified, when conducting the reverse analysis, in three products: Jangada furniture line, Superpop washing machine and Duo Flux flushing valve. 
Additional elements (i.e. innovation vectors) could be examined considering products from other areas (e.g. computer segment, industrial devices, packaging solutions, among others). However, this would fall outside the scope of this study. Another consequence of the research conducted was the derivation of so-called "general conditions". These conditions help in framing an alternative solution, when assessing its innovation potential, considering the elements defined. Table 6 contains a mapping of the components elicited and the two general conditions established. It is observed that, in some cases, a factor can comply with two conditions (i.e. C1 and C2). Thus, the innovation potential is considered "perceived" if either, $\mathrm{C} 1$ or $\mathrm{C} 2$ or both conditions are contemplated. For example, for the element "form" to be elicited as a vector of innovation, the proposed solution must fulfill $\mathrm{C} 1$; or $\mathrm{C} 2$; or $\mathrm{C} 1$ and $\mathrm{C} 2$.

Table 6. Conditions that supports characterizing the innovation potential.

\begin{tabular}{|c|c|c|}
\hline Element & Condition $1(\mathrm{C} 1)$ & Condition $2(\mathrm{C} 2)$ \\
\hline Ergonomics & $\begin{array}{l}\text { The product has a distinctive ergonomic design, which is not } \\
\text { found in similar design solutions. }\end{array}$ & $\mathrm{X}$ \\
\hline Form & $\begin{array}{l}\text { The formal solution must be significantly different from } \\
\text { other competing products. }\end{array}$ & $\begin{array}{l}\text { The design solution allows a certain level of customization (e.g. } \\
\text { colours, compositions, textures). }\end{array}$ \\
\hline Function & $\begin{array}{l}\text { Implement new features or add more functions than } \\
\text { concurrent products. }\end{array}$ & $\begin{array}{l}\text { Implement the same function as concurrent products, but in a } \\
\text { distinct approach. }\end{array}$ \\
\hline Manufacturing & The manufacturing process has been simplified or improved. & $\begin{array}{l}\text { The material selected for manufacturing the product presents a } \\
\text { significant differential from its major competitors. }\end{array}$ \\
\hline Technology & $\begin{array}{l}\text { The product contains a technological attribute that is } \\
\text { promptly recognized by the customer. }\end{array}$ & $\mathrm{X}$ \\
\hline Transport & $\begin{array}{l}\text { The approach for packing the product is novel and different } \\
\text { from the company's concurrents. }\end{array}$ & A new approach to transport the product is devised. \\
\hline $\mathrm{X}$ & Not applicable & \\
\hline
\end{tabular}

In order to verify the consistency of the analysis conducted, the set of products was reexamined. However, now the elements (vectors of innovation) were coupled with the "general conditions" defined. The results can be found in Table 7, where the "general condition" now have a particular description, considering specific attributes that can be mapped into the product examined.

Table 7. Innovation vectors versus Framing conditions for the product examined in the reverse analysis activity

\begin{tabular}{|c|c|c|c|c|c|}
\hline Elements & Trilobite Vacuum Cleaner & Jangada Furniture Line & Spirit Ceiling Fan & $\begin{array}{c}\text { Superpop Washing } \\
\text { Machine }\end{array}$ & $\begin{array}{l}\text { Duo Flux Flushing } \\
\text { Valve }\end{array}$ \\
\hline Ergonomics & $\begin{array}{l}\mathrm{C} 1 \text { : the existence of a display } \\
\text { which allows the product } \\
\text { interface "to communicate" } \\
\text { with the user. }\end{array}$ & $\mathrm{X}$ & $\mathrm{X}$ & $\begin{array}{l}\text { C1: The washing machine } \\
\text { provides specific space on } \\
\text { the sides so the user can } \\
\text { carry it without difficulty. }\end{array}$ & $\mathrm{X}$ \\
\hline Form & $\begin{array}{l}\mathrm{C} 1 \text { : product whose formal } \\
\text { design -organic and } \\
\text { harmonious- stands out in } \\
\text { relation to those already on } \\
\text { the market. }\end{array}$ & $\begin{array}{l}\text { C2: a product identity } \\
\text { was valued by } \\
\text { exploring the local } \\
\text { culture characteristics }\end{array}$ & $\begin{array}{l}\text { C1: analogy to aircraft } \\
\text { propellers provided a light } \\
\text { and harmonious formal } \\
\text { solution. } \\
\text { C2: various colour options } \\
\text { allows for a variety of } \\
\text { compositions between fan } \\
\text { and chandelier. }\end{array}$ & $\begin{array}{l}\mathrm{C} 1 \text { : a product with added } \\
\text { value targeted to low } \\
\text { income customers. } \\
\mathrm{C} 2 \text { : first washing machine } \\
\text { with a transparent cover in } \\
\text { the Brazilian market.. }\end{array}$ & $\begin{array}{l}\text { C2: product can } \\
\text { be installed either } \\
\text { vertically } \\
\text { horizontally. }\end{array}$ \\
\hline Funçtion & $\begin{array}{l}\mathrm{C} 1 \text { : allows adjusting the } \\
\text { level of suction. } \\
\mathrm{C} 2 \text { : vacuum cleaner that } \\
\text { executes the cleaning task } \\
\text { and energy replacement } \\
\text { autonomously. }\end{array}$ & $\mathrm{X}$ & $\begin{array}{l}\text { C2: it implements the same } \\
\text { function than competing } \\
\text { fans, but with a } 30 \% \text { better } \\
\text { performance.. }\end{array}$ & $\mathrm{X}$ & $\begin{array}{l}\text { C1: Product } \\
\text { implements an } \\
\text { additional function: } \\
\text { selection the } \\
\text { flushing mode (with } \\
\text { more or less water } \\
\text { use). }\end{array}$ \\
\hline Manufacturing & $\mathrm{X}$ & $\begin{array}{l}\text { C1: the analogy to } \\
\text { constructive system } \\
\text { of a typical raft } \\
\text { has simplified the } \\
\text { production process. } \\
\text { C2: consistent use of } \\
\text { the raw material - } \\
\text { reforested wood. }\end{array}$ & $\begin{array}{l}\mathrm{C} 1 \text { : reduction in the } \\
\text { number of components - } \\
\text { from seven to three, with } \\
\text { no loss of performance. } \\
\mathrm{C} 2 \text { : use of a material that is } \\
\text { lightweight, resistant and } \\
\text { recyclable (polycarbonate). }\end{array}$ & $\begin{array}{l}\mathrm{C} 1 \text { : research and } \\
\text { development in the } \\
\text { manufacturing process } \\
\text { have enabled the } \\
\text { production of transparent } \\
\text { version of the product } \\
\text { without increasing the cost } \\
\text { to the customer. }\end{array}$ & $\mathrm{X}$ \\
\hline
\end{tabular}




\begin{tabular}{|c|c|c|c|c|c|}
\hline Technology & $\begin{array}{l}\text { C1: use of ultrasound to } \\
\text { guide into the room being } \\
\text { cleaned. } \\
\text { Use of magnetic tapes to } \\
\text { define the boundaries of the } \\
\text { area to be cleaned }\end{array}$ & $\mathrm{X}$ & $\mathrm{X}$ & $\mathrm{X}$ & $\mathrm{X}$ \\
\hline Transport & $\mathrm{X}$ & $\begin{array}{l}\text { C1: the product is } \\
\text { disassembable and } \\
\text { collapsible and can be } \\
\text { easily packed. } \\
\text { C2: the customer can } \\
\text { easily assemble the } \\
\text { product. }\end{array}$ & $\mathrm{X}$ & $\begin{array}{l}\mathrm{C} 1 \text { : product is sold } \\
\text { disassembled, in a packing } \\
\text { volume } 40 \% \text { smaller than } \\
\text { similar version. } \\
\text { C2: the customer can take } \\
\text { the washing machine } \\
\text { home on the moment of } \\
\text { purchasing it. }\end{array}$ & $\begin{array}{l}\mathrm{C} 1 \text { : the product } \\
\text { can be adapted to } \\
\text { existing hydraulic } \\
\text { systems. }\end{array}$ \\
\hline $\mathrm{X}$ & Not observed & & & & \\
\hline
\end{tabular}

It is important to notice that, despite an element fulfil, at least, one general condition for each product examined (e.g. form), this does not mean this element is more relevant than others. Similarly, a unique mapping (e.g. technology) is nota demerit for an element being a innovation vector.

Next, a field survey was structured to verify how designers with different levels of experience recognize the elements elicited as valid for characterizing the innovation potential of a design solution. It also aims to capture the perception of the elements relative importance.

\section{Field Survey}

This field survey was designed to obtain information from professionals working with product development, in different areas of industry (e.g. furniture industry, household appliances, electronics, amongst others), that have developed innovative products. In order to maintain confidentiality, those participants were labelled with the letter "P" followed by a number. For example, P3 (participant number three). The number allocation for each participant was at random. Table 8 contains the main characteristics of each professional contacted.

Table 8. Relevant information from professionals that participated in the field survey.

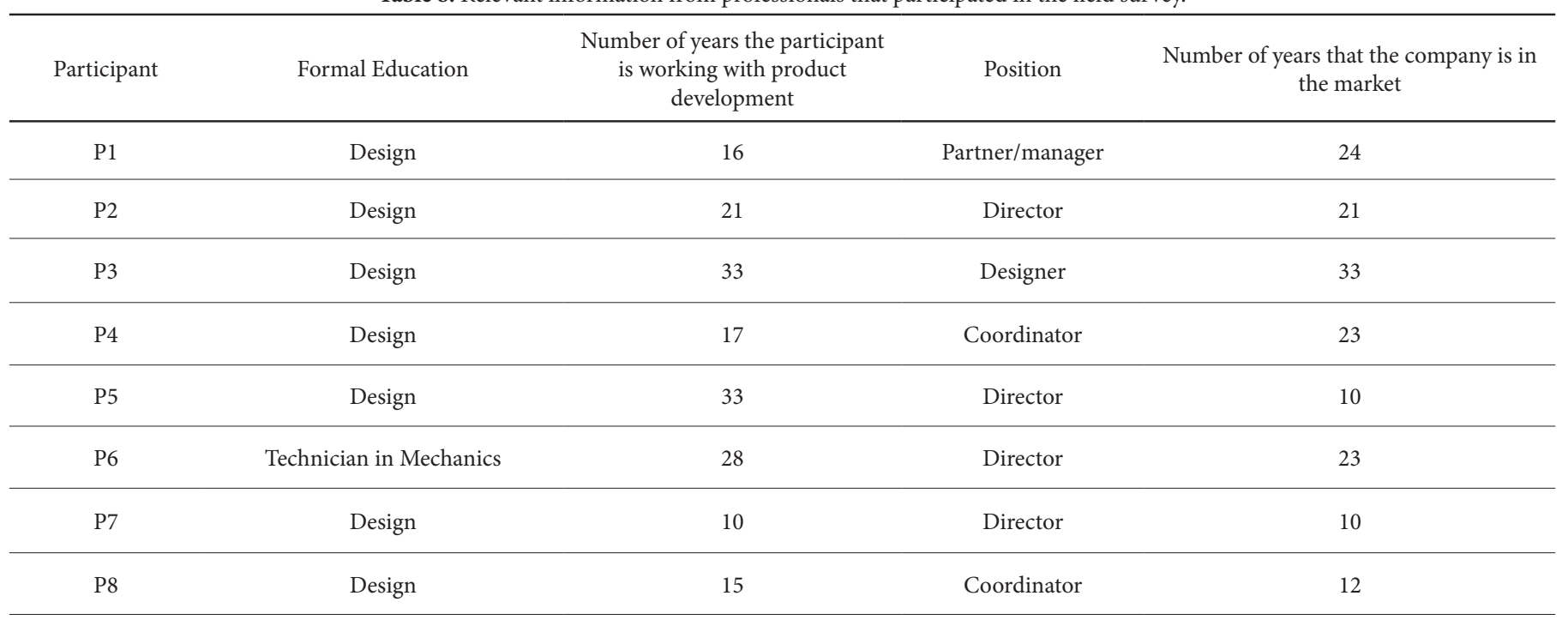

The respondents and companies profile allows inferring that the answers produced are well supported from experiences and practical cases in the product development field. The objectives of the survey were declared through a formal presentation. The data collection instrument was explained. Each participant should assess the level of importance for the elicited elements (innovation vectors) using a scale of 1 to 5 (where: (1) Irrelevant; (2) Not very relevant; (3) Relevant; (4) Very relevant; and (5) Essential).
From the data gathered, the following criteria was established a priori: if for a specific element, all participants should indicate that its level of importance was irrelevant (i.e. scale 1), it should be disregarded (i.e. this element is not perceived as a vector for inducing innovation). It is important to notice that this situation did not occur for this set of elements. The results obtained are shown in Table 9. 
Table 9. Participants' perception of importance value for each element elicited.

\begin{tabular}{|c|c|c|c|c|c|c|c|c|c|c|}
\hline \multirow{2}{*}{ Elements } & \multicolumn{8}{|c|}{ Scale value assigned by the participants } & \multirow{2}{*}{ Total } & \multirow{2}{*}{$\begin{array}{c}\text { Weighted } \\
\text { Value }\end{array}$} \\
\hline & P1 & $\mathrm{P} 2$ & P3 & $\mathrm{P} 4$ & P5 & P6 & P7 & $\mathrm{P} 8$ & & \\
\hline Form & 5 & 4 & 5 & 5 & 4 & 4 & 2 & 3 & 32 & 0,174 \\
\hline Function & 5 & 4 & 3 & 5 & 5 & 5 & 5 & 5 & 37 & 0,201 \\
\hline Manufacturing & 3 & 4 & 5 & 3 & 5 & 4 & 5 & 5 & 34 & 0,185 \\
\hline Transport & & & & & & & & Total & 184 & 1 \\
\hline
\end{tabular}

The same table also shows the relative weight of each element according to the scores given by the respondents. In the above context, it is noted that the element "Function" scored highest, followed by "Manufacturing", "Form", “Technology", "Ergonomics" and "Transport", respectively.
In order to establish a uniform interpretation on the meaning of each element (innovation vector), an individualized statement was defined. All of them begin with the same set of words: "attribute that refers ... " in order to not favour any particular element.

Thus, Table 10 shows the set of elements with their defined statements and specific weighted values, which can be used in a process of assessing the innovation potential of an alternative solution for a design problem.

Table 10. Elements and statements description ranked according to their weighted values.

\begin{tabular}{lll}
\hline \multicolumn{1}{c}{ Element (Relative Weight Value ranking) } & \multicolumn{1}{c}{ Statement description } & Weighted Value \\
\hline Function & Attribute that refers to the product's usage. & 0,201 \\
\hline Manufacturing & Attribute that refers to the product's production. & 0,185 \\
\hline Form & Attribute that refers to the product's aesthetics. & 0,201 \\
\hline Technology & Attribute that refers to presence of technological features in the product & 0,185 \\
\hline Ergonomics & Attribute that refers to the interaction between the customer and the product. & 0,168 \\
\hline Transport & Attribute that refers to approaches to packing/transporting the product. & \\
\hline Total & & \\
\hline
\end{tabular}

\section{Descriptive Application}

In order to verify the response in applying the elicited elements in a project situation, it is proposed a descriptive application considering a product developed and presented in a Brazilian context called, I Paraná Creation, 2002 Edition.

The goal of the Paraná Creation Program (where, I Paraná Creation was one of its initiatives) was to disseminate, between the industries located in the Paraná State-Brazil, the application of industrial design as an innovation tool, through which they could develop competitive products with added value (Centro de Design do Paraná, 2002).

The product selected for running the descriptive application is a portable amplifier device for helping hearing impaired people to improve their auditive capabilities, called "Bio Amp".

The opportunity for developing this product was perceived from the difficulties experimented by people with hearing limitations to have access to portable devices, by either their high costs or their aesthetic aspects (the available products resembled medical devices).
From this context set, the product should meet the following requirements:

a) Be a good quality portable amplifier, which form should map the visual appeal of portable stereos;

b) Be accessible to the hearing impaired people, regardless of their income;

c) Use existing and available technology;

d) Allowing high volume of production;

e) Have compatible dimensions and be easy to transport.

The product should be manufactured by injection split mold, processing ABS material. From the opportunity identification and product design specification, the design team developed three concepts that are illustrated in Table 11.

The three alternative solutions are represented by drawings in perspective, with details, features and specifications described accordingly. 
Table 11. Description of the three Bio Amp proposed conceptual solutions. Source: Centro de Design do Paraná (2002).

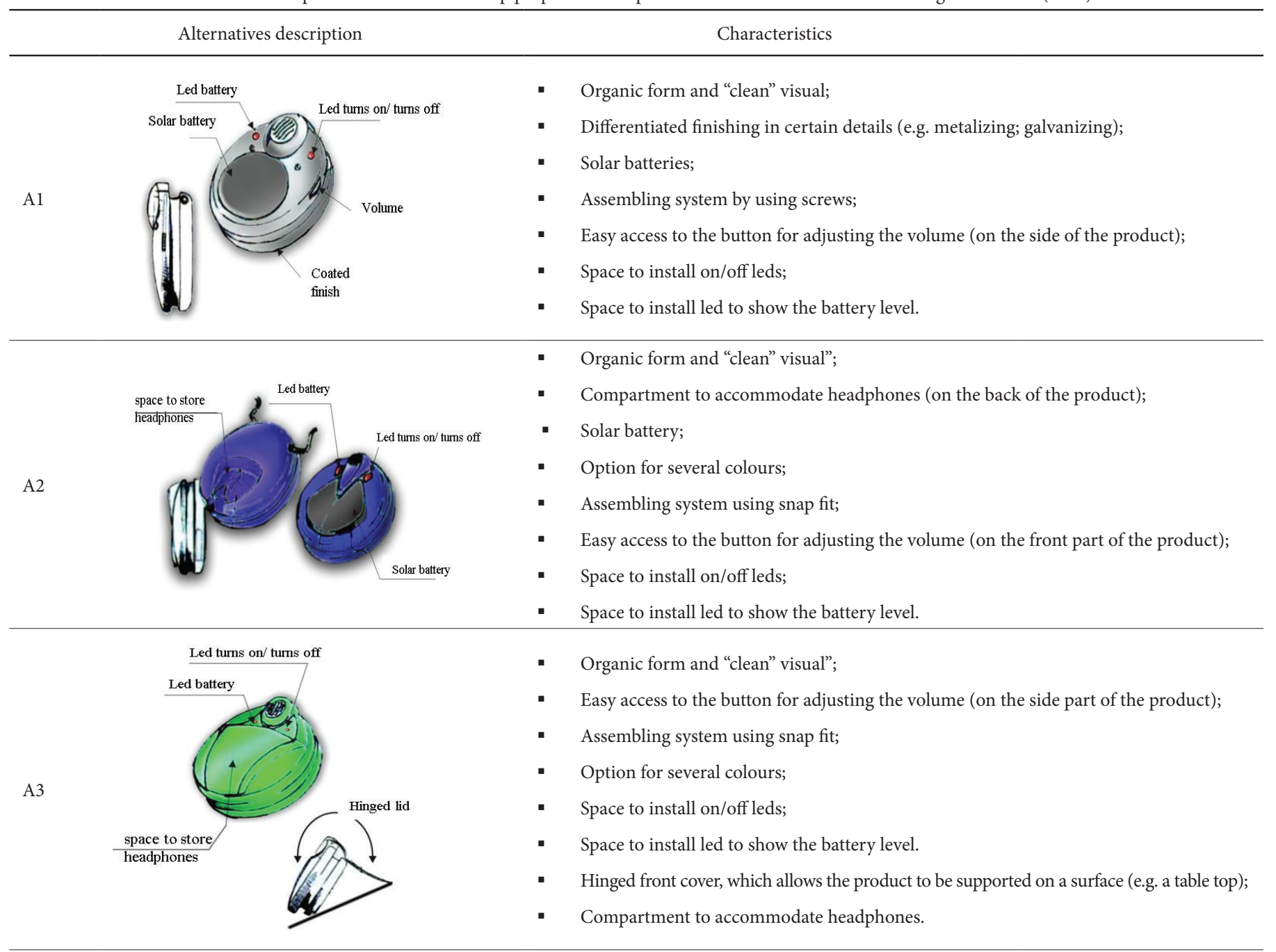

The alternatives in the solution set were examined according to the elements elicited and respective weighted values. For each alternative (A1, A2 and A3) it was checked whether the element maps a framing condition (by an X) or does not map (empty cell) (see Table 12). Each filled cell means that the element's weighted value should be added to the total sum presented on the column "Total". In this assessment procedure, it was verified the presence/absence of the framing conditions presented in Table 6. Thus, it is important to mention that if an alternative fulfils two framing conditions, it does not imply in doubling the weighted value for that element in the total value for that alternative (e.g. despite alternative A1 fulfiling $\mathrm{C} 1$ and $\mathrm{C} 2$ framing conditions for form, the weighted value for the total sum for this element is 0,174 ).

Table 12. Conceptual design alternatives assessment.

\begin{tabular}{|c|c|c|c|c|c|c|c|c|c|c|c|c|}
\hline & Elementè & 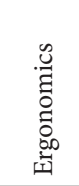 & \multicolumn{2}{|c|}{ हี } & \multicolumn{2}{|c|}{ 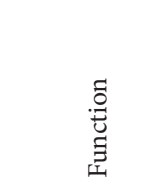 } & \multicolumn{2}{|c|}{ 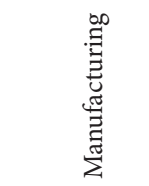 } & \multirow{2}{*}{ 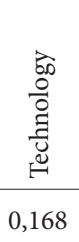 } & \multicolumn{2}{|c|}{ 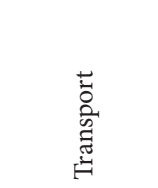 } & \multirow{3}{*}{$\begin{array}{l}\text { (sum of individual } \\
\text { weighted values) }\end{array}$} \\
\hline & Weight Value è & 0,152 & & & & 01 & & & & & & \\
\hline & Framing conditions & $\mathrm{C}$ & $\mathrm{C} 1$ & $\mathrm{C} 2$ & $\mathrm{C} 1$ & $\mathrm{C} 2$ & $\mathrm{C} 1$ & $\mathrm{C} 2$ & $\mathrm{C}$ & $\mathrm{C} 1$ & $\mathrm{C} 2$ & \\
\hline Alternatives & A2 & & $\mathrm{X}$ & $\mathrm{X}$ & $\mathrm{X}$ & & $\mathrm{X}$ & & $\mathrm{X}$ & $\mathrm{X}$ & & 0,848 \\
\hline & A3 & & $X$ & $\mathrm{X}$ & $\mathrm{X}$ & & $X$ & & & & & 0,560 \\
\hline
\end{tabular}


The column on the right end contains the sum of weighted values for each alternative. In this assessment procedure, it was possible to identify that the conceptual proposal A2 presents the greater potential to become an innovative product when compared to the others in the solution set.

It must be noticed that for the proposed assessment routine, there is no need for a developed conceptual solution to meet all framing conditions. Additionally, as a side effect, this assessment highlights where there are gaps in a specific design solution, which, therefore, could be reviewed, in the process of generating other concepts that could present a better potential of innovation.

\section{Results and Discussion}

The global economy is requiring the design team to deliver innovative solutions with regularity and consistency. The innovation process is object of study in different areas. In the product development arena, it is not different.

From examining products already in the market, which are known as being innovative solutions, a set of elements (innovation vectors) have been identified. These elements were contrasted with definitions found in literature. This cross-reference approach validates the set proposed for the context examined. Two framing conditions for characterizing the innovation potential are also suggested.

The results from a field survey show that experienced designers recognize that the elements elicited can map the innovation potential of a conceptual solution. Additionally, for this context, a weight value has been established for each element, which can improve the decision making process.

From a practical case study, the overall evaluation process is detailed, showing that it can be applied during the early stages of design process.

\section{Closing Remarks}

This research confirms that the innovation process cannot be an adhoc activity. On the contrary, it should be structured inside a Product Development Process, with the aim at guiding the decision making routines.

With this study, it was possible to identify a set of elements (innovation vectors) that can map the innovation potential of a conceptual solution for a design problem.

The innovation vectors of innovation are derived from literature support associated with innovative product analysis. A field survey, conducted with experienced designers, recognized the validity of elicited elements for identifying the innovation potential of a conceptual solution.

\section{References}

Back, N; Ogliari, A.; Dias, A; Silva, J. C. da (2008). Integrated product design: planning, conception and modelling. Barueri: Manole. (In Portuguese)

Carvalho, Hélio Gomes de; Reis, Dálcio Roberto dos; Cavalcante, Márcia Beatriz (2011). Innovation Management. Curitiba: Aymará. (In Portuguese)

Centro de Design do Paraná (2002). Criação Paraná / Centro de Design do Paraná. Curitiba: Centro de Design do Paraná. (In Portuguese) Chelles \& Hayashi Design (2016) Retrieved from the Web 6/3/2016. http://www.design.ind.br

Coral, Elisa; Ogliari, André; Abreu Aline França de (2008). Integrated innovation management: strategy, organization and product development. São Paulo: Atlas. (In Portuguese)

Electrolux (2016). Trilobite Vacuum Cleaner Manual. Retrieved from the Web 6/5/2016. http://banksvac.com/media/product_manuals/ electrolux/Electrolux\%20Trilobite.pdf

Grilli, Silvia (2015). Signs of brazilianness in furniture design. São Paulo: SENAI-SP. (In Portuguese)

Li, Wenqiang; Li, Yan; Wang, Jian; Liu, Xiaoying (2010). The process model to aid innovation of products conceptual design. Expert Systems with Applications, 37(5), 3574-3587.

Löbach, Bernd (2001). Industrial design: basis for configuration of industrial products. São Paulo: Edgard Blücher Ltda. (In Portuguese)

Museu da Casa Brasileira (2001a) Poltrona Enora. São Paulo: MCB. Retrieved from the Web 6/5/2016. http://www.mcb.org.br/es/produtos/poltrona-enora

Museu da Casa Brasileira (2001b) Ventilador Spirit. São Paulo: MCB. Retrieved from the Web 6/5/2016. http://www.mcb.org.br/es/produtos/ventilador-de-teto-spirit

Museu da Casa Brasileira (2005) Válvula Duo Flux. São Paulo: MCB. Retrieved from the Web 6/5/2016. http://www.mcb.org.br/pt-BR/ produtos/valvula-duo-flux

Museu da Casa Brasileira (2006) Lavadora Superpop. São Paulo: MCB. Retrieved from the Web 6/5/2016. http://www.mcb.org.br/pt$\mathrm{BR} /$ produtos/lavadora-superpop

OECD (2005). OECD Proposed Guidelines for Collecting and Interpreting Technological Innovation Data. Paris. Oslo Manual.

Padilha, Juliane de Bassi (2008) Tool for Assessing Alternatives During Conceptual Design Stage: an Approach Based on Innovation Criteria, Master Dissertation in Engineering - Post-graduate Programme in Mechanical and Materials Engineering, Federal University of Technology-Paraná, Brazil. (In Portuguese) 
Pahl, G. ; Beitz, W.; Feldhusen, J.; Grote, K-H. (2005). Engineering design a systematic approach. Berlin: Springer.

Rozenfeld, H.; Forcellini, F. A.; Amaral, D. C.; Toledo, J. C.; Silva, S. L.; Alliprandini, D. H.; Scalice. R. K. (2006). Product development management: a reference for process improvment. São Paulo: Saraiva. (In Portuguese)

Sarkar, Prabir; Chakrabarti, Amaresh (2011). Assessing design creativity. Design Studies. 32(4), 348-383.

Toh, Christine A.; Miller Scarlett R (2015). How engineering teams select design concepts: a view through the lens of creativity. Design Studies. 38, 111-138.

Ukko, Juhani; Saunila, Minna (2013).The role of reflection in facilitating and assessing innovativeness. Journal of Technology Management \& Innovation. 8(4), 170-176.
Xie, Xuemei; Fang, Liangxiu; Zeng, Saixing; Huo, Jiage (2016). How does knowledge inertia affect firms product innovation? Journal of Business Research. 69(5), 1615-1620.

Yilmaz, Seda; Seifert, Colleen M. (2011). Creativity through design heuristics: a case study of expert product design. Design Studies. 32(4), 384-415.

Zabala-Iturriagagoitia Jon Mikel (2012). New product development in traditional industries: decision-making revised. Journal of Technology Management \& Innovation, 07(1), 31-51.

Zawislak, Paulo Antônio; Borges, Mauro; Wegner, Douglas; Santos, André; Castro-Lucas, Cristina (2008). Towards the innovation function. Journal of Technology Management \& Innovation. 3(4), 17-30. 